\title{
THE IMPACT OF INNOVATION STRATEGY ON ORGANIZATIONAL LEARNING AND INNOVATION PERFORMANCE: DO FIRM SIZE AND OWNERSHIP TYPE MAKE A DIFFERENCE?
}

\author{
K.T.Beyene ${ }^{1,2 *}$, C.S.Shi ${ }^{1} \&$ W.W. $\mathrm{Wu}^{1}$
}

\section{ARTICLE INFO}

\section{Article details}

Submitted by authors 28 Jul 2015

Accepted for publication 21 Feb 2016

Available online $\quad 10$ May 2016

The authors want to thank Mekelle University (Ethiopian Institute of

Technology) for the financial support provided through the research grant, $\mathrm{EiT}-\mathrm{M} / \mathrm{RB} / 01 / 2013$

Contact details

* Corresponding author milmatkin@hit.edu.cn

Author affiliations

1 Harbin Institute of Technology, School of Management, China

2 Department of Industrial

Engineering, Mekelle University, Ethiopia

DOI

http://dx.doi.org/10.7166/27-1-1308

\section{ABSTRACT}

Though innovation strategy and organizational learning have been credited to impact on product innovation performance, they have been rarely considered in a single model simultaneously. Thus, the main aim of the paper is to investigate the extent of impact of innovation strategy on organizational learning and product innovation performance. A structural equation modelling analysis was performed on the survey data collected from Ethiopian textile and leather product manufacturing firms. The result reveals that innovation strategy is positively related to product innovation performance. Further, firm size and ownership type moderate the effect of innovation strategy on product innovation performance.

\section{OPSOMMING}

Alhoewel daar erken word dat innovasiestrategie en organisatoriese-leer produkinnovasievertoning beïnvloed, word dit selde gelyktydig in ' $n$ enkele model oorweeg. Die doel van die artikel is dus om die invloedsbereik van innovasiestrategie op organisatoriese-leer en produkinnovasievertoning te ondersoek. ' $n$ Strukturelevergelykingsmodellering analise is op opname data van ' $n$ Etiopiese tekstiel- en leerproduk vervaardigers gedoen. Die resultaat toon dat innovasiestrategie positief verwant is aan produkinnovasiesvertoning. Verder is daar gevind dat maatskappy grootte en eienaarskaptipe die invloed van innovasiestrategie op produkinnovasievertoning matig.

\section{INTRODUCTION}

Though product innovation is long been considered to be the key source of competitive advantage and social wellbeing $[1,2]$, there still is an ongoing debate about the source of new product idea. Some scholars advocate the importance of staying closer to the customer and competitor at the market and learn directly from the external environment. On the other hand, others advance the notion that an emphasis on the external business environment will lead only to trivial product generations and will not support long term profit. For the later, the development of internal competence and innovation capability is the only source of profit and market share sustainability.

The paper investigates the extent of impact of innovation strategy on the learning activity and innovation performance of manufacturing firms. More specifically, it examines the impact of technology push and market pull innovation strategies on organizational learning and product innovation performance. It considers the perspective of the manufacturing firms in one of the least developed but emerging economies in Africa, Ethiopia. As a new economic player in the international arena, Ethiopia has registered a quite significant economic development in the last two decades. Consequently, while the contribution of the agriculture sector to the GDP is getting lower and lower annually, the manufacturing sector is slowly picking the pace. With further development in the supportive infrastructure, it is believed that Ethiopia will be a hub of manufacturing firms in the continent in the next decade. However, as new entrant to the international market, a question remains if the manufacturing sector currently operating under 
protection policy and quota market could sustain the global competition and make profit out of it. Related to the issue of profit and market share sustainability for the firms, the question of innovation strategy they pursued and its impact on their learning and innovation performance is worth of consideration.

According to Samara, Georgiadis and Bakouros [3] product innovation is the generation diffusion and translation of customer, competitor and technology related information into products of higher value. Saeed, Yousafzai, Paladino and De Luca [4] also note that product innovation is an organizational renewal process resulting from the incorporation of internal and external knowledge. This is also shared by Kim and Lee [5] and Wang and Wang [6] who advance that product innovation is a knowledge intensive organizational process that entirely depends on individual and group learning. While organizational leaning is credited for its influence on the product innovation performance of manufacturing firms, it need the support of strategic focus [7]. Through strategic focus, organizations decide whether their learning activity is based on the internal or external environment. According to Saeed et al. [4] and Day [8], among others, manufacturing firms have the option of pursuing either Technology-push or Market-pull strategies in their new product development process.

Though the issue of the impact of strategy on product innovation performance of firms have got an immense scholarly attention, most of the studies were over emphasized and dominated by the consideration of the market pull strategy. The conclusions of the existing literatures were mostly drawn by considering the manufacturing firms in the most developed economies and there still exists a gap with respect to the least developed economies in Africa [9, 10]. Therefore, by considering the textile and leather product manufacturing firms in Ethiopia, the paper aims too achieve two main objectives. First, it will examine the extent of impact of technology push and market pull innovation strategies on the product innovation performance. Second, it investigates the mediating role of organizational learning and the moderating role of both firm size and ownership type.

By addressing the aforementioned objectives from the least developed economies' perspective, the paper contributes to the theory of innovation management in various ways. First, the paper further details product innovation performance by dividing it into project performance and commercial performance. The project performance concerns with the overall organization's effort invested to innovate faster, cheaper and with high quality. On the other hand, the commercial performance is the market success of newly introduced products measured in terms of the financial gain and the level of customer satisfaction imported. Second, the paper provides a better insight into the significance of the mediating role of organizational learning on the relationship between innovation strategy and product innovation performance.

The remainder of the paper is organized as follows. The second section presents the literature review along the hypothesis to be tested. The third section deals with the methodology employed to collect and analyze the survey data. The results of the analysis is presented in the fourth section followed by the related discussion. Finally, the implications of the findings as well as the limitations of the study and suggestions for future research are described.

\section{LITERATURE REVIEW}

Manufacturing firms of varying size in both developed and developing countries are operating under highly uncertain and dynamic market conditions [11, 12]. According to Frambach, Prabhu and Verhallen [13], such market conditions along with the turbulence of technology are forcing manufacturing firms to look for alternative way of survival and growth. And for many of these firms innovation in general and product innovation in particular has long been considered as the primary source of strategic competitive advantage. In light of this importance, a substantial number of scholarly work has given immense attention to the investigation of factors that enhance innovativeness and boost product innovation performance $[14,15]$. With respect to recent works by Kim and Lee [5] and Wang and Wang [6], innovation is a knowledge intensive organizational process that entirely depends on the individual and group learning activities within an organization. In support of the notion Martin-de Castro et al. [15] point out that, continued innovation and innovation performance in an organization will be impossible without a deliberate and continuous learning activity. However, effectiveness of the learning activity of an organization 
is also arguably influenced by the type of strategy organizations pursued in their innovation process [16].

\subsection{Product innovation performance}

The intensity of competition and rate of change in customer taste are currently forcing manufacturing firms to generate new products at faster rates and lower costs $[17,18]$. According to Kok and Beimans [14] product innovation is a core organization process that creates superior customer values and supports the overall organizational performance. Different scholars described product innovation performance in various ways. Zakic and his colleagues for instance considered product innovation performance to be the market success of newly introduced products [19]. On the other hand, for Menguc and Auh [11], product innovation performance is a continuous organizational performance measured by the commercial outcome, the level of customer satisfaction and the overall project performance of the innovation process.

The paper considers product innovation to be the totality of both the commercial performance and the project performance. The commercial performance is the market success of a new product related to its effect on the financial performance and the level of customer satisfaction imported due to its introduction $[19,20]$. The project performance of an innovation process on the other hand is related to the internal efficiency. The project performance is the total effort an organization invested on the innovation process and is manifested through the speed of innovation, the quality of the final product and the overall cost reduction effort [21-23].

\subsection{Innovation strategy}

The extent of organization's emphasis on either the internal or external knowledge has been credited to have an influence on the innovation performance of manufacturing organizations. Consequently, organizations have the option of pursuing either the technology push or market pull innovation strategy in their new product generation and development process [4]. From strategic management perspective, both the technology push and market-pull innovation strategies strive for the achievement of superior innovation performance through the development of organizational competence [4, 24]. According to Day [8] firms pursuing the technology push innovation strategy usually allocates enough R\&D resources, acquire new technology, and accumulate better human resource competence. Such capabilities and competences are hard to be imitated by competitors and have considerable long term effect on the product innovation performance. Recent research findings by Paladino [25] and Saeed et al. [4] empirically indicated that the technology push innovation strategy helps organizations to build better confidence and enable them to exploit the knowledge in their external environment easily. Even though many of the existing literatures claim that the technology-push innovation strategy contributes better to product innovation capability and innovation performance, firms have difficulty to develop it [8].

On the other hand, the proponents of the market-pull innovation strategy have long been arguing that for better performance organizations need to stay close to the customer they serve and the competitors engaged with [24, 26]. In supporting the notion, Calantone, Cavusgil and Zhao [27] also state that organizations that deliberately focus on the external environment (the market) as the source of their innovation idea will learn better and outperform their counterparts. Market pull strategy is an organization wide generation, translation and interpretation of customer and competitor related information to provide products of superior value and stay at the top of the competition [28]. According to Jeong, Pae and Zhou [26] and Calantone et al. [27], the market pull strategy helps organizations to forecast unmet market needs and align their response accordingly.

In general, while the question about source of product innovation is the subject of an ongoing debate, researchers agree on the point that firms need strategic focus to boost their product innovation performance. Zhang et al. [29] for instance conclude that organization's strategy will influence the direction and source of their learning and influence their performance. In addition, recent works by Al-Ansari, Altalib and Sardoh [30] and Martin de-Castro, Delgado, Navas and Cruz [31] empirically concluded that both the technology-push and market pull strategies have influence on product innovation performance. Thus, by combining the findings of the existing literatures and taking the Ethiopian manufacturing environment into consideration, we hypothesized that

$\mathrm{H}_{1}$ : Both the Technology-push and Market-pull innovation strategies are positively and significantly related to the product innovation performance of firm's innovation process. 
However, some studies argue that the presence of strategy by itself is not an end that influences the innovation performance [32, 33]. Accordingly, most of the differences in the product innovation performance among firms is credited to the difference in other management practices. The finding by Baker and Sinkula [24] for instance indicated that, the knowledge source, the pace of learning and the amount of tangible and intangible resource allocated are the reflection of organization's strategy. Therefore, with the Ethiopian case, by considering the financial and nonfinancial problems to develop internal capability up to the requirement of technology push strategy, we hypothesized that

$\mathrm{H}_{2}$ : The market-pull innovation strategy has relatively higher effect on the product innovation performance than the technology-push strategy.

\subsection{The mediating role of organizational learning}

Much as the selection, formulation and implementation of appropriate innovation strategy is credited to the impact on the product innovation performance of a firm, strategy by itself is not an end. For that, the impact of innovation strategy on the product innovation performance of firms is reflected through other management activities including the learning efforts [4,16, 34].

Product innovation is a knowledge intensive process that entails individual and group learning [5, 6]. In supporting the notion, Martin De-Castro [15] stated that continuous innovation and innovation performance will be Impossible without a deliberate and continuous organizational learning. Organizations shape the behavior of their members though learning activities and influence their overall performance. Organizational learning according to Calntone et al. [27] is a knowledge creation process largely related to the acquisition, dissemination and interpretation of customer and competitor related information. For Yu and his colleagues organizational learning is an effort that strives to harness intellectual and social capital of organizational members through which it boosts their competence [35].

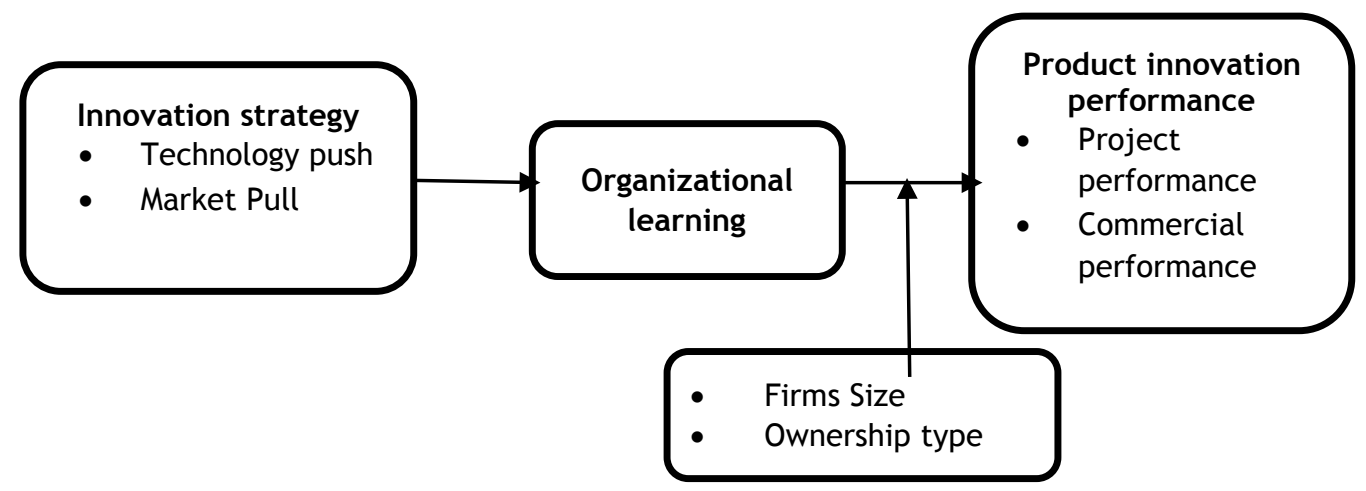

Figure 1: Conceptual framework

Extant literatures consider organizational learning to be composed of four components namely information acquisition, information dissemination, shared interpretation and organizational memory building [36-38]. The information acquisition component is the effort of an organization invested to attain necessary information, knowledge and capacity for the innovation process. According to Segaro, Larimo and Jones [39] the information acquisition entails organizational commitment, learning culture and efforts for experimentation. Once information is collected, it should be distributed to the different units in the organization. Hence, the concern of research with respect to this component is the speed of information flow and the quality of information at its destination. The faster the information is disseminated, the faster and better the learning effort of organizations [40].

While the information acquisition and dissemination efforts are important aspects of learning, some researchers claim that it is the shared interpretation of the information that brings effect to the innovation process [41, 42]. Different units in an organization have different need for information. Thus, a simple distribution of acquired information without directed interpretation will result in disintegrated learning effort. Hence, Vijande and his colleagues [40] argue that learning effort of an organization should be directed by a predefined strategic objective that can lead to shared interpretation of the information. By the selection, formulation and 
implementation of appropriate innovation strategy, organizations influence the direction and source of their learning activity. According to Huber [36] the effort also shapes the behavior of organizational members and impacts their overall performance. Hence, with respect to the efforts of the manufacturing organizations in Ethiopian, we hypothesized that

$\mathrm{H}_{3}$ : The interrelationship between innovation strategy and product innovation performance is fully mediated by the learning activity of the organizations.

\subsection{The moderating role of firm size and ownership type}

It is the notion of the contingency theory that the strategy choice of an organization need to have a fit with the overall organizational factors as well as its external environment [4]. Consequently, we were interested to examine if firm size and ownership structure have influence on the level of interaction between product innovation strategy and innovation performance of the manufacturing firms in the country.

\subsubsection{Small vs. Large size firms}

The size of an organization is related to the availability of resources and affects the level of motivation and expectation of organizational members has a role to play in building employee confidence and boosting performance. A recent study by Gebreeyesus [43] on the case of African manufacturing firms indicated that contrary to developed economies' around $60 \%$ of small firms in Africa exit the market in their third year of establishment. Moreover a sub-Saharan countries related work by Van Beisebroek [44] concluded that larger firms experience higher productivity and better performance than their small counterparts. In summary, because of the resource availability and the level of confidence developed by members, firm's size influences the level of both project and commercial performance of the innovation process [45]. Therefore, with respect to the Ethiopian manufacturing firms, we hypothesized that

$\mathrm{H}_{4}$ : The impact of both technology-push and market-pull innovation strategies on product innovation performance is higher in larger firms than medium sized firms.

\subsubsection{Private Vs. public firms}

In addition to the firm's size, extant literatures also empirically show that the type of ownership of manufacturing organizations has influence on their product innovation performance. Many instances indicated that public firms have higher investment and contribute huge employment opportunities lower efficiency in resource deployment makes them lower performers [45, 46]. In addition, by considering the case of Chinese manufacturing firms Zhang et al. [46] empirically showed that public manufacturing firms spend far lower on R\&D than private firms. In general, the overall indication of existing findings is that partially or fully privatized manufacturing firms have far better product innovation performance than the publicly owned ones. Therefore, with respect to Ethiopian manufacturing firms we propose the hypothesis that

$\mathrm{H}_{5}$ : The impact of both technology-push and market-pull innovation strategies on product innovation performance is higher in private firms than public firms

\section{METHODOLOGY}

\subsection{Data and sample selection}

The proposed hypotheses were tested by means of mail survey data collected from large and small sized textile and leather product manufacturing firms in Ethiopia. Both the selected sectors are considered to be economically important for the nation and are given primary consideration by the national government [47]. Moreover, as a new entrant to the international market, the firms need strategic focus which will create and motivate the opportunity of learning and boost performance. The final population includes 127 manufacturing firms each with more than 10 employees. In accordance to Dillman [48], ten questionnaires along with a cover letter stating the objective of the study and a prepaid envelop was sent to the human resource department of each organization to be distributed among the management members [6, 49]. A total of 432 (out of 1502) usable questionnaires, 286 from textile and 146 from leather manufacturing firms (total response rate of $29 \%$ ) were collected back. In both sectors, most of the respondents were male $(87 \%)$ consisting of $4.4 \%$ general managers, $23 \%$ production managers, $4.2 \%$ Project managers, $15 \%$ Marketing and sales managers, 7.9\% Facility managers, 10.9\% Quality managers, 10.4\% Design managers, 10.2\% R\&D 
managers, $6.7 \%$ financial managers and $7.2 \%$ human resource managers. Respondents also have an average working experience of 6.3 years in the case of the textile industry and 4.6 years in the leather industry in their current position.

\subsection{Measurement}

The use of constructs plays an important role in designing a survey instrument in management research [50]. Further different researchers found that there exists a correlation between subjective and objective measures and most research works in the field of management used subjective measures $[50,51]$. Thus, the limited availability and accessibility of objective measures [52] forces us to use subjective measures for all the constructs. Measures for all the constructs were adopted from existing literatures with a slight modification to the context of the study area under consideration and each of the constructs is described below.

Innovation strategy: is an organizational philosophy and behavior directed on understanding the current and future needs of the market and adapting organizational response accordingly [38]. Measurement items were adapted from Frambach et al. [13] and Jeong et al. [26]. Respondents were asked for their opinion about the level of influence of the orientation items on their learning efforts. Items were measured on a 5-point Likert scale ranging from ' 1 ' (=very low) to ' 5 ' (=Very high)

Organizational learning: is an organizational characteristic that shows an effort to understand the customer and competitor at the market and help an organization to exploit the opportunities in the business environment [53]. Measurement items focusing on information acquisition, information dissemination and shared interpretation were adapted from Segaro et al. [39]. Items were measured on a 5 point Likert scale ranging from ' 1 ' (=strongly disagree) to ' 5 ' (=strongly agree).

Product innovation performance: In line with Menguc and Auh [11], the paper divides product innovation performance into two sub constructs, Project performance and commercial performance. Measurement items were adapted from Bodlaj [32], Wang and Wang [6] and Kessler and Bierly [22]. A 5-point Likert scale ranging from ' 1 ' (=totally disagree) to '5' (=totally agree). Respondents were asked to compare the innovation performance of their firm against the key competitors.

\section{RESULT}

\subsection{Statistical analysis}

To test the proposed hypotheses about the interrelationship among innovation strategy, organizational learning and product innovation performance, the paper uses survey data from Ethiopia. Before the actual survey, the questionnaire which contains measurement items from existing literatures was tested in two stages. First the draft questionnaire was given to academic experts teaching and researching in the field $(\mathrm{N}=3)$ and their comments about the content and clarity were incorporated in the semi-final questionnaire. Second, the semi-final questionnaire was sent to management members working in two large textile and one leather factors $(N=12)$. At the end of this stage, any ambiguous or unclear parts were either modified or deleted. A total of 1502 questionnaires were distributed among the middle and top management members of participating manufacturing firms and 432 usable questionnaires were collected back.

In testing the interrelationship among the constructs, the paper deploys the maximum likelihood estimation method of structural equation modeling (SEM) using Amos v 20.0. In the analysis, the raw survey data was used as input and latent variables were manifested as an average of each respondent. The data was checked for the assumptions of multivariate normality and linearity [54] and the final result shows that the assumptions were not violated.

The measurement model was evaluated by using the convergent and discriminant validity tests. The convergent validity is the degree to which measurement factors supposed to measure a given construct do agree to each other [6]. Similarly, the discriminant validity is the degree to which factors supposed to measure particular construct do not conceptually predict unrelated criteria [6, 55]. The convergent validity was tested by using the factor loading, which should be more than 
Table 1: Convergent and discriminant validity test results

\begin{tabular}{|c|c|c|c|c|c|}
\hline Factors & Items & $\begin{array}{l}\text { Factor loading } \\
\text { (t-value) }\end{array}$ & $C-a$ & CR & AVE \\
\hline Technology & TEPU1 & $0.68\left(14.954^{* *}\right)$ & & & \\
\hline \multirow[t]{4}{*}{ push (TECPUS) } & TEPU2 & 0.78 (r.i) & & & \\
\hline & TEPU3 & $0.71\left(15.482^{* *}\right)$ & 0.79 & 0.80 & 0.66 \\
\hline & TEPU4 & $0.70\left(13.173^{* *}\right)$ & & & \\
\hline & TEPU5 & $0.69\left(13.018^{* *}\right)$ & & & \\
\hline \multirow{5}{*}{$\begin{array}{l}\text { Market Pull } \\
\text { (MARPUL) }\end{array}$} & MAPU1 & $0.82\left(17.470^{* *}\right)$ & & & \\
\hline & MAPU2 & 0.72 (r.i) & & & \\
\hline & MAPU3 & $0.70\left(15.272^{* *}\right)$ & 0.87 & 0.84 & 0.62 \\
\hline & MAPU4 & $0.72\left(15.789^{* *}\right)$ & & & \\
\hline & MAPU5 & $0.68\left(14.459^{* *}\right)$ & & & \\
\hline \multirow{11}{*}{$\begin{array}{l}\text { Organizational } \\
\text { learning } \\
\text { (ORGLEA) }\end{array}$} & COLE1 & $0.73(16.306)$ & & & \\
\hline & COLE2 & 0.75 (r.i.) & & & \\
\hline & COLE3 & $0.80\left(17.517^{* *}\right)$ & & & \\
\hline & COLE4 & $0.74\left(14.370^{* *}\right)$ & & & \\
\hline & OPMI1 & $0.79\left(22.120^{* *}\right)$ & & & \\
\hline & OPMI2 & $0.88(r . i)$ & & & \\
\hline & OPMI3 & $0.77\left(21.560^{* *}\right)$ & 0.84 & 0.72 & 0.52 \\
\hline & OPMI4 & $0.66\left(17.351^{* *}\right)$ & & & \\
\hline & SHVI1 & $0.83\left(21.097^{* *}\right)$ & & & \\
\hline & SHVI2 & 0.87 (r.i) & & & \\
\hline & SHVI3 & $0.69\left(15.301^{* *}\right)$ & & & \\
\hline \multirow{5}{*}{$\begin{array}{l}\text { Commercial } \\
\text { performance } \\
\text { (COMPER) }\end{array}$} & FIPE1 & 0.72 (16.859) & & & \\
\hline & FIPE2 & 0.78 (r.i) & & & \\
\hline & FIPE3 & $0.79\left(18.220^{* *}\right)$ & 0.89 & 0.92 & 0.71 \\
\hline & CUSA 1 & $0.67\left(16.622^{* *}\right)$ & & & \\
\hline & CUSA2 & 0.88 (r.i) & & & \\
\hline \multirow{9}{*}{$\begin{array}{l}\text { Project } \\
\text { performance } \\
\text { (PROPER) }\end{array}$} & INSP1 & $0.67\left(15.349^{* *}\right)$ & & & \\
\hline & INSP2 & 0.74 (r.i) & & & \\
\hline & INSP3 & $0.84\left(17.676^{* *}\right)$ & & & \\
\hline & INQU1 & $0.79\left(22.474^{* *}\right)$ & & & \\
\hline & INQU2 & 0.92 (r.i) & 0.80 & 0.83 & 0.74 \\
\hline & INQU3 & $0.73\left(20.009^{* *}\right)$ & & & \\
\hline & COST1 & $0.84\left(21.189^{* *}\right)$ & & & \\
\hline & COST2 & 0.87 (r.i) & & & \\
\hline & cosT3 & $0.68\left(15.215^{* *}\right)$ & & & \\
\hline
\end{tabular}

0.5 , composit reliability (CR) which exceed 0.6 for all constructs and the average variance extracted (AVE) which need to be more than 0.5. As Table 1 shows, all the factor loeading, the composite reliability and the average variance extracted exceeds the aformentioned criterias and signifies the adequacy of the convergent validity result. The discriminant validity was evaluated by comparing the square root of the AVE of each construct with the correlation values of the construct with the other constructs [56]. Accordigly as can be seen from Table 2 (the bold diagonal values), we found that all the AVE values fullfil the criteria hence, the mesurement items have acceptable descriminant validiy.

\subsection{Hypothesis testing}

The correlation matrix in Table 2 is an indication about the significance of the relationship innovation strategy (Technology push and Market-pull), organizational learning and product innovation performance (Project performance and commercial performance). Considering these significant relationships, we develop a theoretical model that considers the technology-push and market-pull innovation strategies as direct antecedents of organizational learning. For analysis purposes, the organizational learning was considered as a single construct predicted by knowledge acquisition, knowledge dissemination and shared interpretation.

The result of the analysis reveals that both the technology push and market-pull innovation strategies have significant positive relationship with project performance and commercial performance of firm's innovation process. From the total effect decomposition result in Table 3, the technology push exerts an effect of $(B=0.115, p<0.001)$ and $(B=120, p<0.001)$ on project performance and commercial performance respectively. Similarly, the market-pull strategy had an effect of $(B=0.326, p<0.001)$ on project performance and $(B=0.341, p<0.001)$ on commercial performance. A close examination of the result also reveals that the market pull innovation 
strategy has three times as much effect on project performance and commercial performance than the technology push innovation strategy.

The result of the analysis also shows that both technology push and market pull innovation strategies have highly significant positive relationship with the organizational learning. Furthermore, we also found significant positive relationship between organizational learning and both Project and commercial performances. With that kind of significant antecedent and consequence relationship, we become interested to examine if organizational learning plays a significant mediating role on the relationship between innovation strategy and product innovation performance. The significance of the mediating role was tested by using the four conditions of Baron and Kenny [57]. Consequently, we found that the effect of both technology push and market pull innovation strategies on both the project and commercial performances were fully mediated by organizational learning.

Table 2: Descriptive statistics and correlation

\begin{tabular}{|c|c|c|c|c|c|c|c|c|}
\hline & \multirow[b]{2}{*}{ Construct } & \multirow[b]{2}{*}{ Mean } & \multirow[b]{2}{*}{ SD } & \multicolumn{5}{|c|}{ Pearson's correlation } \\
\hline & & & & 1 & 2 & 3 & 4 & 5 \\
\hline 1 & Technology push & 3.46 & 0.63 & 0.81 & & & & \\
\hline 2 & Market pull & 3.46 & 0.73 & $0.43^{* *}$ & 0.79 & & & \\
\hline 3 & Organizational learning & 3.72 & 0.77 & $0.31^{\text {*t }}$ & $0.34^{* *}$ & 0.72 & & \\
\hline 4 & Project performance & 3.70 & 0.69 & $0.15^{* *}$ & $0.23^{* *}$ & $0.36^{* *}$ & 0.84 & \\
\hline 5 & Commercial performance & 3.49 & 0.65 & $0.54^{* *}$ & $0.41^{* *}$ & $0.30^{* *}$ & $0.12^{*}$ & 0.86 \\
\hline
\end{tabular}

Table 4 presents the moderator analysis result of both firm size and ownership type. The first model (Model 1), with a reasonable model fit, indicates the result for small and large size manufacturing firms in Ethiopia. The result reveals that the relationship between technology push innovation strategy and product innovation performance were stronger for larger firms as compared to the effect of on small firms. Thus, consistent with the proposed hypothesis $\left(\mathrm{H}_{4}\right)$, the technology push innovation strategy exerts an effect of $B_{\text {project }}=0.12, p<0.005$ and $B_{\text {commercial }}=0.10$, $\mathrm{p}<0.005$ in the case of small firms. But, the effect with respect to larger manufacturing firms, $\left(B_{\text {project }}=0.20, p<0.001\right.$ and $\left.B_{\text {commercial }}=0.22, p<0.001\right)$ is a bit higher and significant at different level. However, the relationship between market pull innovation strategy and both project and commercial performance didn't show any significant difference between small and large manufacturing firms (See the result of model 1 in Table 4). Consequently, the forth hypothesis $\left(\mathrm{H}_{4}\right)$ holds true partially.

The result of model 2 in Table 4 on the other hand presents the moderating effect of ownership type. The result consistent with proposed hypothesis $\left[\mathrm{H}_{5}\right]$ and in line with the findings of existing literatures (See for instance Cuaresma et al. [46]) shows that the relationship between innovation strategy and product innovation performance were stronger for private manufacturing firms than the public ones. With respect to the large manufacturing firms, while the technology-push innovation strategy has an effect of $B_{\text {project }}=0.25, p<0.001$ and $B_{\text {commercial }}=0.24, p<0.001$, the market push strategy exerts an impact of $B_{\text {project }}=0.47, p<0.001$ and $B_{\text {commercial }}=0.55, p<0.001$. Meanwhile, the market pull and the technology push strategies exert an effect of $\left(B_{\text {project }}=0.17, p<0.001\right.$ and $\left.B_{\text {commercial }}=0.22, p<0.001\right)$ and $\left(B_{\text {project }}=0.20, p<0.005\right.$ and $\left.B_{\text {commercial }}=0.19, p<0.005\right)$ respectively in the case of small sized firms.

\section{DISCUSSION AND CONCLUSION}

As source of key strategic competitive advantage, the technology push and market pull innovation strategies attract the attention of both managers and academics. According to their respective advocators, both strategies enable organizations to exploit their internal and external business environment at different degrees [4]. While the technology push innovation strategy focuses more on the resource competence and internal capability development, the market pull gives more emphasis to external information related to the customer and competitor at the market $[4,8]$.

Regardless of the substantial depth of research work on the issue, the relative importance of the technology push and market pull innovation strategies as source of innovation idea still remains the subject of an ongoing debate [4, 7]. In one hand, the market pull strategy proponents argue 
Table 3: Effect Decomposition

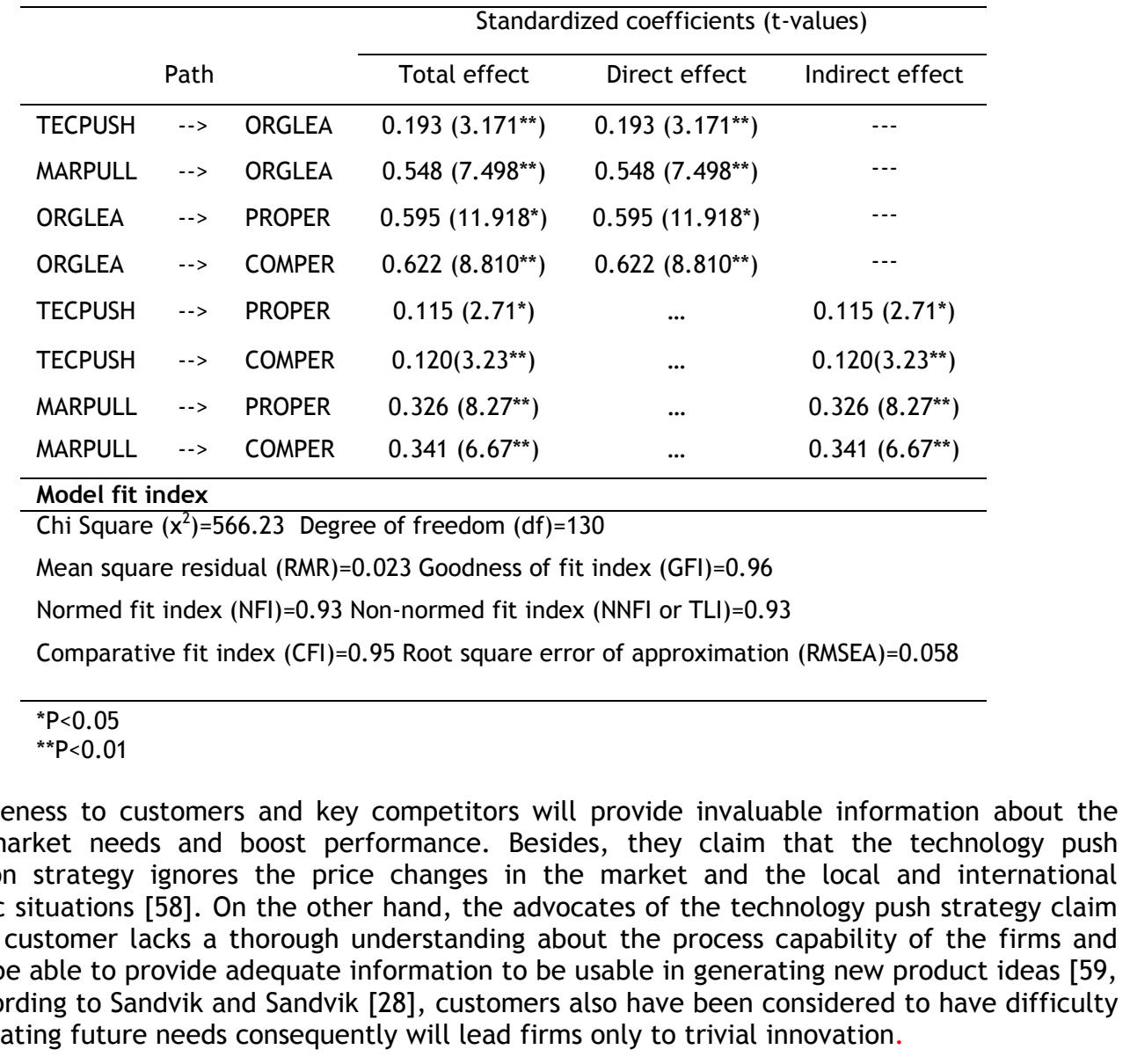

By considering the aforementioned arguments concerning the relative importance of the technology push and market pull innovation strategies, the paper develops an alternative model. The model developed further details and elaborates the relationship among innovation strategy (technology push and market pull), organizational learning and product innovation performance (Project performance and commercial performance).

The analysis result based on the developed theoretical model reveals some important insight and will contribute to the innovation management theory in various ways. First the result will provide evidence from the least developed economies perspective and the manufacturing firms will develop better insight about the interrelationship among the constructs. Consistent with the existing literatures, the paper provides a supportive evidence that with the current technological, economic and human resource competence the manufacturing firms in Ethiopia will better benefit by focusing on the market pull innovation strategy. Meanwhile, consistent with the findings of Saeed et al. [4], the result also shows that the technology push strategy significantly impacts on the product innovation of the firms. This particular case is especially true with respect to large private manufacturing firms. In the case of the large private manufacturing firms, the result might provide a supportive indication that the experience from market pull innovation along with some investment could support easy transition to the technology push strategy.

Further, the paper details product innovation performance by dividing it into project performance and commercial performance. The selection of appropriate innovation strategy along with the support of organizational learning is believed to bring change in the innovation capability and marketing skills of organizational members [36, 61]. The development of these skills and capabilities in turn will facilitate the innovation process, reduce the associated costs, introduce quality, and through improving customer satisfaction, it will ensure the financial gains of the firms [27]. Therefore, the model that contains detailed relationships among innovation strategy 
(technology push and market pull), organizational learning and product innovation performance (Project performance and commercial performance), will serve as an alternative analysis model for further studies.

The paper also contributes to the innovation management theory by examining the significance level of the mediating role of organizational learning on the relationship between innovation strategy and product innovation performance. The positive and significant relationship between the antecedent (innovation strategy) and organizational learning as well as the consequence (Product innovation performance) and organizational learning were indications of the significance of the mediating role. Further evaluation of the four criteria of Baron and Kenny [57] reveal that the relationship between innovation strategy and product innovation performance is fully mediated by the organizational activities related to learning. More specifically, the result in line with the findings of Saeed et al. [4] and Paladino [25] shows that the way an organization acquires, disseminates and interprets customer and competitor related information, fully influences the effect of the innovation strategy on its product innovation performance.

Finally, the paper examines the moderating effect of firm size and ownership type on organizational learning and innovation performance. Recent findings by Gebreyesus [43] and Van Biesebroeck [44] indicated that larger manufacturing firms in sub-Saharan countries have higher productivity and performance than their medium size counterparts. The result of our analysis shows that the effects of technology push innovation strategy on both project and commercial performances were much stronger in the case of large than small manufacturing firms. However, when it comes to the effect of the market-pull -innovation strategy on product innovation performance, there was no significant difference between large and small size manufacturing firms. The higher effect of technology push innovation strategy on the product innovation performance of large firms is believed to have some connection with resource availability and competence [46].

On the other hand, the result with respect to the moderating role of ownership type was consistent with the findings of existing literatures (see for example [45, 46]). With that respect, the result shows the effect of both the technology push and market pull strategies on the product innovation performance are higher in the case of privately owned manufacturing firms. According to Zhang et al. [46], the lack of resource deployment efficiency and low R\&D budget might lower the effect of innovation strategy on product innovation performance of public firms.

As for the relative importance of the two innovation strategies, the effect of market push innovation strategy on the project and commercial performance was stronger in the case of large and privately owned firms. Therefore, with the current technological set up, resource competence and macro-economic situation of Ethiopia, all the firms, small/large sized, as well as private/public owned will have better product innovation performance by deliberately focusing on the market pull innovation strategy.

Finally, the paper has some limitations that need further consideration in future research so as to have a generalized conclusion about the case of Ethiopian manufacturing sector. First it considers the technology push and market pull innovation strategies as separate constructs without giving space for the possibility of coexistence. Secondly, the survey data considers only the middle and top management members of each firm and since product innovation performance needs total effort and commitment of organizational members, input from employees might be required in future works.

\section{REFERENCES}

[1] Herrera, L. \& M. Nieto. 2008. The national innovation policy effect according to firm location. Technovation, 28(8): pp. 540-550.

[2] Samara, E., P. Georgiadis, \& I. Bakouros. 2012. The impact of innovation policies on the performance of national innovation systems: A system dynamics analysis. Technovation, 32 (11), pp. 624-638. doi: 10.1016/j.technovation.2012.06.002.

[3] Saeed, S., Yousafzai, S., Paladino, A., \& De Luca, L. M. 2015. Inside-out and outside-in orientations: A meta-analysis of orientation's effects on innovation and firm performance. Industrial Marketing Management, 47, pp.121-133. 
[4] Kim, W. J., \& Lee, J. D. 2009. Measuring the role of technology-push and demand-pull in the dynamic development of the semiconductor industry: the case of the global dram market. Journal of Applied Economics, 12(1), pp. 83-108.

[5] Wang, Z., \& Wang, N. 2012. Knowledge sharing, innovation and firm performance. Expert Systems with Applications, 39(10), pp. 8899-8908.

[6] Di Stefano, G., Gambardella, A., \& Verona, G. 2012. Technology push and demand pull perspectives in innovation studies: Current findings and future research directions. Research Policy, 41(8), pp.1283-1295

[7] Day, G. S. 2011. Closing the marketing capabilities gap. Journal of Marketing, 75(4), pp.183-195.

[8] Amoako-Gyampah, K. 2003. The relationships among selected business environment factors and manufacturing strategy: insights from an emerging economy. Omega-International Journal of Management Science, 31(4), pp. 287-301. doi: 10.1016/s0305-0483(03)00049-5

[9] Hoskisson, R. E., Eden, L., Lau, C. M., \& Wright, M. 2000. Strategy in emerging economies. Academy of Management Journal, 43(3), pp. 249-267. doi: 10.2307/1556394.

[10] Menguc, B., \& Auh, S. 2010. Development and return on execution of product innovation capabilities: The role of organizational structure. Industrial Marketing Management, 39(5), pp. 820-831.

[11] Laforet, S. (2008). Size, strategic, and market orientation affects on innovation. Journal of Business Research, 61(7), pp. 753-764.

[12] Frambach, R. T., Prabhu, J., \& Verhallen, T. M. 2003. The influence of business strategy on new product activity: The role of market orientation. International Journal of Research in Marketing, 20(4), pp. 377-397.

[13] Kok, R. A., \& Biemans, W. G. 2009. Creating a market-oriented product innovation process: a contingency approach. Technovation, 29(8), pp. 517-526.

[14] Martín-de Castro, G., Delgado-Verde, M., Navas-López, J. E., \& Cruz-González, J. 2012. The moderating role of innovation culture in the relationship between knowledge assets and product innovation. Technological Forecasting and Social Change, 80(2), pp. 351-363.

[15] Baker, W. E., \& Sinkula, J. M. 1999. The synergistic effect of market orientation and learning orientation on organizational performance. Journal of the Academy of Marketing Science, 27(4), pp. 411-427.

[16] Nieto, M. J., \& Santamaría, L. 2007. The importance of diverse collaborative networks for the novelty of product innovation. Technovation, 27(6), pp. 367-377.

[17] Kessler, E. H. 2000. Tightening the belt: methods for reducing development costs associated with new product innovation. Journal of Engineering and Technology Management, 17(1), pp. 59-92.

[18] Zakić, N., Jovanović, A., \& Stamatović, M. 2008. External and internal factors affecting the product and business process innovation. Facta universitatis-series: Economics and Organization, 5(1), pp. 17-29.

[19] Rodríguez-Pinto, J., Rodríguez-Escudero, A. I., \& Gutiérrez-Cillán, J. 2012. How market entry order mediates the influence of firm resources on new product performance. Journal of Engineering and Technology Management, 29(2), pp. 241-264

[20] Carbonell, P., \& Rodriguez, A. I. 2006. The impact of market characteristics and innovation speed on perceptions of positional advantage and new product performance. International Journal of Research in Marketing, 23(1), pp. 1-12.

[21] Kessler, E. H., \& Bierly, P. E. 2002). Is faster really better? An empirical test of the implications of innovation speed. Engineering Management, IEEE Transactions on, 49(1), pp. 2-12.

[22] Lin, B. W. , \& Chen, J. S. 2005. Corporate technology portfolios and R\&D performance measures: a study of technology intensive firms. R\&D Management, 35(2), pp. 157-170.

[23] Baker, W. E., \& Sinkula, J. M. 2007. Does market orientation facilitate balanced innovation programs? An organizational learning perspective. Journal of Product Innovation Management, 24(4), pp. 316-334.

[24] Paladino, A. 2009. Financial Champions and Masters of Innovation: Analyzing the Effects of Balancing Strategic Orientations. Journal of Product Innovation Management, 26(6), pp. 616-626.

[25] Jeong, I., Pae, J. H., \& Zhou, D. 2006. Antecedents and consequences of the strategic orientations in new product development: The case of Chinese manufacturers. Industrial Marketing Management, 35(3), pp. 348-358.

[26] Calantone, R. J., Cavusgil, S. T., \& Zhao, Y. 2002. Learning orientation, firm innovation capability, and firm performance. Industrial Marketing Management, 31(6), pp. 515-524.

[27] Sandvik, I. L., \& Sandvik, K. 2003. The impact of market orientation on product innovativeness and business performance. International Journal of Research in Marketing, 20(4), pp. 355-376.

[28] Zhang, J., Hoenig, S., Di Benedetto, A., Lancioni, R. A., \& Phatak, A. 2009. What contributes to the enhanced use of customer, competition and technology knowledge for product innovation performance?: A survey of multinational industrial companies' subsidiaries operating in China. Industrial Marketing Management, 38(2), pp. 207-218.

[29] Al-Ansari, Y., Altalib, M., \& Sardoh, M. 2013. Technology Orientation, Innovation and Business Performance: A Study of Dubai SMEs. The International Technology Management Review, 3(1), pp. 1-11.

[30] Martín-de Castro, G., Delgado-Verde, M., Navas-López, J. E., \& Cruz-González, J. 2013. The moderating role of innovation culture in the relationship between knowledge assets and product innovation. Technological Forecasting and Social Change, 80(2), pp. 351-363.

[31] Bodlaj, M. 2011. The impact of a responsive and proactive market orientation on innovation and business performance. Economic and Business Review, 12(4), pp. 241-261.

[32] Langerak, F., Hultink, E. J., \& Robben, H. S. 2004. The impact of market orientation, product advantage, and launch proficiency on new product performance and organizational performance. Journal of Product Innovation Management, 21(2), pp. 79-94. 
[33] Narver, J. C., Slater, S. F., \& MacLachlan, D. L. 2004. Responsive and Proactive Market Orientation and New-Product Success*. Journal of Product Innovation Management, 21(5), pp. 334-347.

[34] Yu, Y., Dong, X.-Y., Shen, K. N., Khalifa, M., \& Hao, J.-X. 2013. Strategies, technologies, and organizational learning for developing organizational innovativeness in emerging economies. Journal of Business Research, 66(12), pp. 2507-2514.

[35] Huber, G. P. 1991. Organizational learning: The contributing processes and the literatures. Organization science, 2(1), pp. 88-115.

[36] Hult, G. T. M., Snow, C. C., \& Kandemir, D. 2003. The role of entrepreneurship in building cultural competitiveness in different organizational types. Journal of management, 29(3), pp. 401-426.

[37] Jiménez-Jiménez, D., \& Sanz-Valle, R. 2011. Innovation, organizational learning, and performance. Journal of Business Research, 64(4), pp. 408-417.

[38] Segaro, E. L., Larimo, J., \& Jones, M. V. 2014. Internationalization of family small and medium sized enterprises: The role of stewardship orientation, family commitment culture and top management team. International business review, 23(2), pp. 381-395.

[39] Santos-Vijande, M. L., Lopez-Sanchez, J. A., \& Gonzalez-Mieres, C. 2012. Organizational learning, innovation, and performance in KIBS. Journal of Management \& Organization, 18(6), pp. 870-904.

[40] Chen, C.-J., \& Huang, J.-W. 2007. How organizational climate and structure affect knowledge management-the social interaction perspective. International Journal of Information Management, 27(2), pp. 104-118.

[41] Chen, C. J., \& Lin, B. W. 2004. The effects of environment, knowledge attribute, organizational climate, and firm characteristics on knowledge sourcing decisions. R\&D Management, 34(2), pp. 137-146.

[42] Gebreeyesus, M. 2008. Firm turnover and productivity differentials in Ethiopian manufacturing. Journal of Productivity Analysis, 29(2), pp. 113-129.

[43] Van Biesebroeck, J. 2005. Firm size matters: Growth and productivity growth in African manufacturing. Economic Development and Cultural Change, 53(3), pp. 545-583.

[44] Cuaresma, J. C., Oberhofer, H., \& Vincelette, G. A. 2012. Firm growth and productivity in Belarus: new empirical evidence from the machine building industry. World Bank Policy Research Working Paper (6005).

[45] Zhang, A., Zhang, Y., \& Zhao, R. 2003. A study of the R\&D efficiency and productivity of Chinese firms. Journal of Comparative Economics, 31(3), pp. 444-464.

[46] Lemma, T., Tegegne, A., \& Hoekstra, D. 2012. Capacity for knowledge-based smallholder agriculture in Ethiopia: Linking graduate programs to market-oriented agricultural development: Challenges, opportunities and IPMS experience: ILRI (aka ILCA and ILRAD).

[47] Dillman, D. A. 1978. Mail and telephone surveys (Vol. 3): Wiley Interscience.

[48] Dibrell, C., Craig, J. B., \& Hansen, E. N. 2011. How managerial attitudes toward the natural environment affect market orientation and innovation. Journal of Business Research, 64(4), pp. 401-407.

[49] García-Morales, V. J., Jiménez-Barrionuevo, M. M., \& Gutiérrez-Gutiérrez, L. 2012. Transformational leadership influence on organizational performance through organizational learning and innovation. Journal of Business Research, 65(7), pp. 1040-1050.

[50] Dess, G. G., \& Robinson, R. B. 1984. Measuring organizational performance in the absence of objective measures: the case of the privately-held firm and conglomerate business unit. Strategic Management Journal, 5(3), pp. 265-273.

[51] Morgan, R. E., \& Strong, C. A. 2003. Business performance and dimensions of strategic orientation. Journal of Business Research, 56(3), pp. 163-176.

[52] Mahmood, R., \& Hanafi, N. 2013. Learning Orientation and Business Performance of Women-Owned SMEs in Malaysia: the Mediating Effect of Competitive Advantage. British Journal of Arts \& Social Sciences, 11(2).

[53] Byrne, B. M. 2013. Structural equation modeling with AMOS: Basic concepts, applications, and programming: Routledge

[54] Kline, R. B. 2011. Principles and practice of structural equation modeling: Guilford press.

[55] Fornell, C., \& Larcker, D. F. 1981. Evaluating structural equation models with unobservable variables and measurement error. Journal of marketing research, pp. 39-50.

[56] Baron, R. M., \& Kenny, D. A. 1986. The moderator-mediator variable distinction in social psychological research: Conceptual, strategic, and statistical considerations. Journal of personality and social psychology, 51(6), pp. 1173.

[57] Wei, Y. H., \& Wang, Q. O. (2011). Making sense of a market information system for superior performance: The roles of organizational responsiveness and innovation strategy. Industrial MarketingManagement,40(2),pp.267-277.doi: 10.1016/j.indmarman.2010.06.039

[58] Naranjo-Gil, D. 2009. The influence of environmental and organizational factors on innovation adoptions: Consequences for performance in public sector organizations. Technovation, 29(12), pp. 810818

[59] Camps, J., \& Rodriguez, H. 2011. Transformational leadership, learning, and employability Effects on performance among faculty members. Personnel Review, 40(4), pp. 423-442. doi: $10.1108 / 00483481111133327$

[60] Dicle, Ü., \& Köse, C. 2014. The Impact of Organizational Learning on Corporate Sustainability and Strategy Formulation with the Moderating Effect of Industry Type. Procedia-Social and Behavioral Sciences, 150. pp. 958-967. 